\title{
Analysis of Free Residual Chlorine in Drinking Water Distribution Systems in Ore Processing Industry
}

\author{
Arif Susanto ${ }^{1,2,3 *}$, Uli Amrina ${ }^{3}{ }^{4 * *}$, Purwanto Purwanto ${ }^{1,5}$, Edi K. Putro ${ }^{3,6}$, \\ Wiliam E. Yochu ${ }^{3,6}$, John C. Wilmot ${ }^{7}$ \\ ${ }^{1}$ Green Technology Research Center, Doctorate Program of Environmental Science, School of Postgraduate Studies, \\ Universitas Diponegoro, Semarang 50241 \\ ${ }^{2}$ Department of Environmental Engineering, Faculty of Civil and Planning Engineering, \\ University of Kebangsaan Republic of Indonesia, Bandung 40263 \\ ${ }^{3}$ Occupational \& Environmental Health, Department of Resources Management, \\ Concentrating Division of PT Freeport Indonesia, Tembagapura 9990 \\ ${ }^{4}$ Department of Environmental Engineering, Faculty of Engineering, University of Indonesia, Depok 16424 \\ ${ }^{5}$ Department of Chemical Engineering, Faculty of Engineering, University Diponegoro, Semarang 50275 \\ ${ }^{6}$ Safety, Health \& Environmental, Resources Management Department, \\ Concentrating Division of PT Freeport Indonesia, Tembagapura 99960 \\ ${ }^{7}$ Department of Mill Operation, Concentrating Division of PT Freeport Indonesia, Tembagapura 99960
}

Received: 14 January 2020

Accepted: 4 April 2020

\begin{abstract}
The ability to obtain high-quality drinking water is dependent on the level of routine and sustainable management of the Drinking Water Distribution System (DWDS). This is also due to the continuous variation, degradation, and interaction in the quality of river water sources that need to fulfill the physical, chemical and microbiological health requirements of humans to avoid problems. Therefore, a high level of effort is needed to monitor the chemical and biological parameters of the distribution system and to determine the free residual chlorine (FRC) is $0.2 \mathrm{mg} / \mathrm{L}$ with a maximum starting point of $1 \mathrm{mg} / \mathrm{L}$ along the piping network which is influenced by bulk and wall reactions. This research aims to analyze, simulate and manage water distribution piping systems and the result can be used to evaluated alternative strategies for improving water quality, to design and upgrade the performance of a hydraulic system, and to realize assessment about FRC consumer exposure in the ore processing of the Concentrating Division of PT Freeport Indonesia, using EPAnet 2.0 software. The results showed that the hydraulic simulation of the distribution network using the gravity system was adequate in terms of high pressure. By using field measurement data, the average constant of the decayed FRC is 0,00033 ,
\end{abstract}

*e-mail: arifssnt@yahoo.com

**e-mail: amrinauli0@gmail.com 
and the result are 6 nodes with FRC levels between 0.1 to $0.2 \mathrm{mg} / \mathrm{L}$ were obtained using 1 booster on the Water Treatment Plant.

Keywords: Drinking Water Distribution Systems, Free Residual Chlorine, water quality modeling, EPAnet

\section{Introduction}

Based on the measurement results from Indonesia Meteorology Climatology and Geophysics Council (BMKG), Tembagapura is categorized as a place with the highest average monthly rainfall of $1,011.5 \mathrm{~mm}$ [1]. Therefore, the availability of abundant drinking water is obtained through proper treatment. This is also supported by the policy on the Constitution of the Republic of Indonesia Number 18 of 2008 in article 19 regarding waste management. It was also followed up with a circular letter of the Ministry of Environment and Forestry of the Republic of Indonesia Number SE.3/UM/RT/SET.1/2/20018 on the ban of the use of plastic in packaging drinking water in mining industries [2].

Drinking water is a major human need, where the human body needs water for life of 30-6- liter per day. However, physical, chemical and biological contamination tends to occur in water sources which are dependent on geological conditions or industrial and agricultural activities [3]. These contaminants occur when there are various impurities in the form of microorganisms that come in contact with bodies of water or are dissolved in water carried from one place to another. [4]. Drinking water needs to fulfill the physical, chemical and microbiological requirements, to avoid health-related problems. The most impurity of biological traits that cause human health or cause death $[4,5]$. Human health is greatly influenced by various agents such as pathogens, bacteria, various minerals, and organic substances present in unsafe drinking water [6]. A significant proportion of the population in developing countries suffer health problems due to unsafe drinking water. According to the International Union on Conservation of Nature (IUCN) report, as many as $60 \%$ of infant deaths are caused by waterrelated diarrhea which is the highest ratio in Asia [4]. Pathogens that are present in drinking water such as viruses, bacteria, protozoa cause 2.5 million deaths from the diarrheal disease each year [7]. Other waterrelated diseases are typhoid, giardiasis, intestinal worms, diarrhea, cryptosporidium infections, and gastroenteritis [6]. The growth of microorganisms in drinking water distribution systems can be related to pipe corrosion and the production of various elements and sediments such as iron, total organic carbon (TOC), phosphorus, manganese and aluminum [8-10].

An indicator of microbial pollution in water is total coliform and Escherichia coli (E. coli). In some countries, such as Ethiopia, $45.7 \%$ of drinking water is contaminated with coliform [11], while in India,
$36 \%$ does not fulfill the bacteriological requirements [12]. Appropriate treatments must be used to eliminate the presence of E. coli and total coliform in raw water.

Adequate treatment is carried out on drinking water to ensure the quality distributed through piping networks fulfills the requirements in accordance with the Regulation of the Minister of Health of the Republic of Indonesia Number 492/MENKES/PER/IV/2010. The main purpose of this treatment is to produce tasteless, odorless, and colorless water that does not pose a risk to consumers' health [13]. In drinking water distribution systems, it is possible for changes in water quality, especially in terms of biology, such as the presence of pathogenic bacteria that enters the pipeline due to leakage. Therefore, there is a need to disinfect drinking water to ensure it is free from bacteria using chlorine compounds [14].

The concentration of free residual chlorine (FRC) is promoted in the Guidelines for Drinking-Water Quality regulated by the World Health Organization (WHO). Based on Surface Water Treatment Rule by Mays (2000) and WHO (2011), the minimum and maximum required FRC levels are $0.2 \mathrm{mg} / \mathrm{L}$ and $5.0 \mathrm{mg} / \mathrm{L}$, respectively $[15,16]$. Another research stated that the maximum affixing concentration to the reservoir is $1 \mathrm{mg} / \mathrm{L}$. The concentration of FRC in drinking water distribution systems is dependent on the chlorine decay rate and water age which are affected by the hydraulic conditions in the pipeline network. The chlorine decay rate is further influenced by the value of bulk and pipe wall reactions [17]. The decay due to bulk reaction is affected by water temperature and the amount of reactive organic carbon, while the chlorine decay due to pipe wall reaction is influenced by the degree of corrosion or biofilm and the pipe's age [16, 17].

Free residual chlorine (FRC) is needed to ensure the control of certain pathogenic organisms contained in water. It also prevents the growth of certain pathogenic organisms as long as the water is in the pipeline [18]. FRC levels that are too high has the ability to accelerate corrosion in pipes, thereby, leading to the creation of taste and odor in water [19]. It also enters the body and compound with organic substances such as urine or sweat; therefore, it produces nitrogen trichlorine compounds. These compounds irritate body cells, gastrointestinal disorders, anemia and an increase in absorption of chlorine. Therefore, to maintain the existence of $\mathrm{FRC}$, at the appropriate concentration value, an analysis of the water distribution network system is required. 


\section{Methods}

This research was conducted to model and simulate the drinking water distribution system in the ore processing area at the Concentrating Division of PT Freeport Indonesia from August to December 2019. The various model inputs are shown in Fig. 1.

In general, the data needed to carry out the process of drinking water distribution network simulation includes physical network data, interconnection, water resources, network accessories, and chlorine trace. Primary data were collected through field surveys by determining the pipe type, diameter, length, valve type, water distribution system, and chlorine injection dose. Secondary data obtained from the number of employees and the pattern of drinking water demand. The information was then processed and modeled using simulations of the hydraulic parameters and resulting

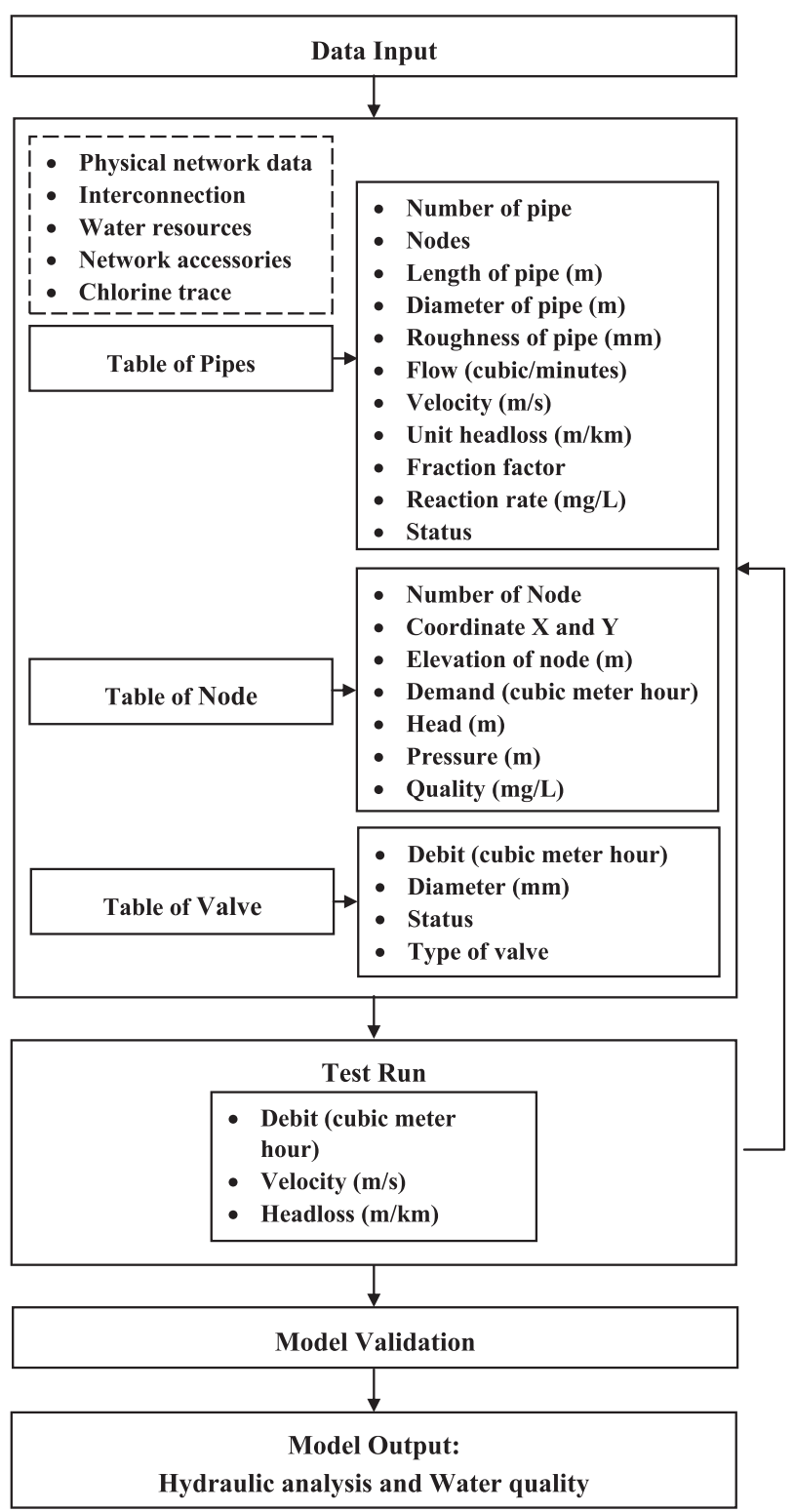

Fig. 1. Research implementation method. water quality. The nodes or pipes were re-checked with the implementation process carried out using actual measurements for the FRC concentration. In addition, the EPAnet 2.0 software, a Windows-based computer program was used for analysis.

Epanet 2.0 is a simulation program of time development with a hydraulic profile used for the treatment analysis of clean water quality in a distribution pipeline network. It consists of a point/ node/junction pipe, pump, valves (accessories), ground, and elevated reservoirs. The generated output includes the pipe inflow $(\mathrm{L} / \mathrm{sec})$, water pressure from each point/ node/junction used to determine the installation, pump and reservoir operations.

EPAnet 2.0 is a tool designed to determine the development, movement, and degradation of water and its chemical elements using various distribution systems, design details, hydraulic calibration models, residual chlorine analysis and several other elements.

This type of simulation was carried out using the extended period simulation (EPS) system, where the analysis was based on fluctuations in water demand in 24 hours. The simulated hydraulic parameters were flow, velocity, water pressure level, and loss. In addition, the simulated water quality parameters were the chlorine decay rate due to bulk and pipe wall reactions.

\section{Results and Discussion}

\section{Drinking-Water Distribution Network System}

The drinking water distribution system in the Concentrating Division of PT Freeport Indonesia uses a gravity system, with a significant difference in elevation from upstream to downstream with the ability to produce high pressure. The link and node components were used to represent the drinking water distribution network in the field using EPAnet 2.0 as shown in Fig. 2. The link component is an interconnection of pipes where water entered or left the distribution system through nodes. It consists of pumps and valves, while the nodes consist of a junction, reservoir and tank [17].

The source of water supply at the research location came from the reservoir which is a Dam channeled through the pipeline to the treatment plant. The volume of stored water in the treatment tank tends to vary based on time duration with a basic cylindrical elevation of $0.05 \mathrm{~m}$ and an initial chlorine quality of $1 \mathrm{mg} / \mathrm{L}$. The basic input of tank consisted of elevation (m), maximum and minimum water levels (m), tank diameter $(\mathrm{m})$, and water quality at the initial level $(\mathrm{mg} / \mathrm{L})$.

The computed results of the tank consist of the demand and pressure that varies at each time. Highdensity polyethylene (HDPE) pipes ranging from $1 / 2$ inch diameter to 4 inch diameter are used in the junction. The advantages of HDPE include resistance to corrosion/cracking/earthquake damages, lightweight, and having a slippery/smooth surface [12]. The basic 

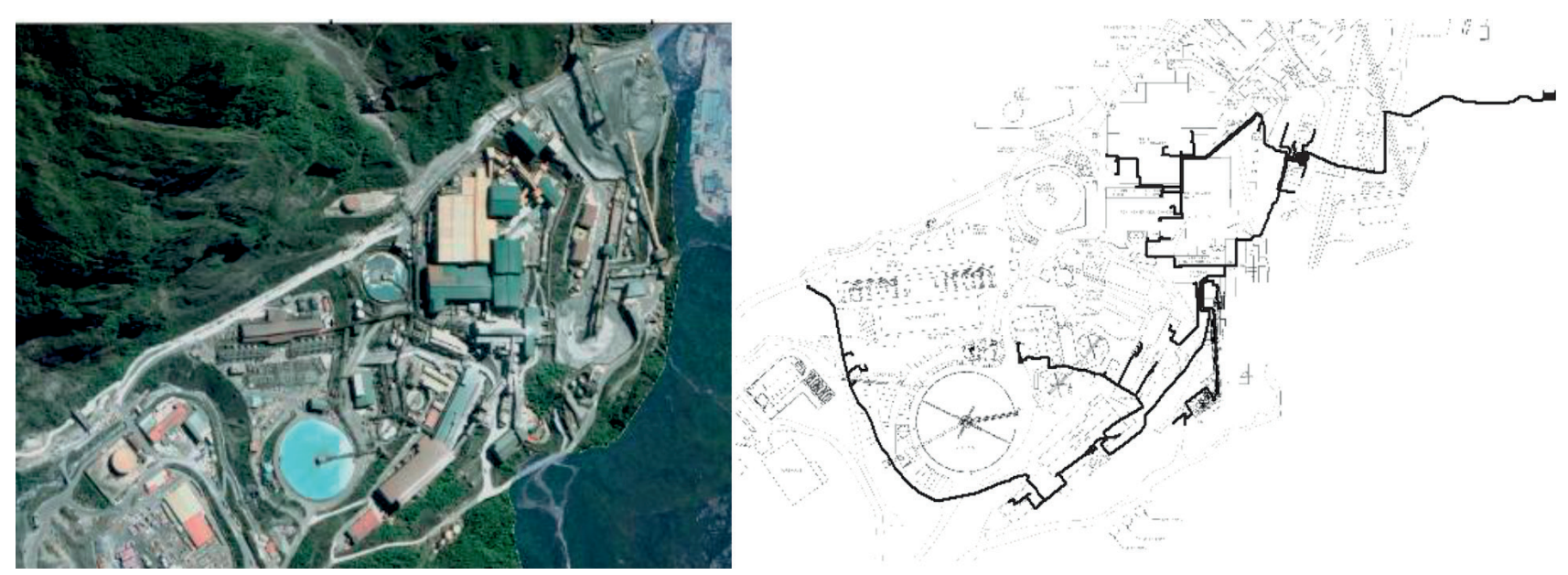

Fig. 2. Topography and layout of the drinking water distribution network systems in the ore processing industry.

pipe input consisted of initial and final node data, length (meters), diameter (millimeter), roughness coefficient value and its initial status (open or closed). The computational results from the software gave flow volume in LPS (liters per second), flow velocity in $\mathrm{m} / \mathrm{s}$, headloss in units of $\mathrm{m} / \mathrm{km}$, and water quality for FRC concentrations in $\mathrm{mg} / \mathrm{L}$. A total of 191 pipes were used in the drinking water distribution network system.
A junction is a point on the network where lines meet and water entered or left the network. The basic input of junctions in this research included elevation in meters (m), water demand measured in LPS and initial water quality for chlorine concentration in $\mathrm{mg} / \mathrm{L}$. The number of junctions in the distribution network of this research consisted of 203 connections as shown in Fig. 2. The computational results for the entire

Table 1. Water quantity as a multiplier for time intervals.

\begin{tabular}{|c|c|c|c|c|c|c|c|c|c|c|c|c|}
\hline \multicolumn{13}{|c|}{ The time pattern to the multiplier for pattern 1 - Office } \\
\hline Periode & 1 & 2 & 3 & 4 & 5 & 6 & 7 & 8 & 9 & 10 & 11 & 12 \\
\hline Multiplier & 1 & 0 & 0 & 0.4 & 0.6 & 1 & 0.8 & 0.6 & 0.4 & 0.6 & 0.8 & 1 \\
\hline Periode & 13 & 14 & 15 & 16 & 17 & 18 & 19 & 20 & 21 & 22 & 23 & 24 \\
\hline Multiplier & 0.8 & 0.6 & 0.4 & 0.6 & 0.8 & 0.6 & 0.4 & 0.2 & 0 & 0 & 0 & 0 \\
\hline \multicolumn{13}{|c|}{ The time pattern to the multiplier for pattern 2 - Steady day shops } \\
\hline Periode & 1 & 2 & 3 & 4 & 5 & 6 & 7 & 8 & 9 & 10 & 11 & 12 \\
\hline Multiplier & 1 & 0 & 0 & 0.4 & 0.6 & 1 & 0.8 & 0.6 & 0.4 & 0.6 & 0.8 & 1 \\
\hline Periode & 13 & 14 & 15 & 16 & 17 & 18 & 19 & 20 & 21 & 22 & 23 & 24 \\
\hline Multiplier & 0.8 & 0.6 & 0.4 & 0.6 & 0.8 & 0.6 & 0.4 & 0.2 & 0 & 0 & 0 & 0 \\
\hline \multicolumn{13}{|c|}{ The time pattern to the multiplier for pattern 3 -Shift shops } \\
\hline Periode & 1 & 2 & 3 & 4 & 5 & 6 & 7 & 8 & 9 & 10 & 11 & 12 \\
\hline Multiplier & 1 & 0.2 & 0.4 & 0.6 & 0.8 & 1 & 0.8 & 0.6 & 0.4 & 0.6 & 0.8 & 1 \\
\hline Periode & 13 & 14 & 15 & 16 & 17 & 18 & 19 & 20 & 21 & 21 & 23 & 24 \\
\hline Multiplier & 1 & 0.6 & 0.6 & 0.6 & 0.8 & 1 & 0.8 & 0.6 & 0.6 & 0.4 & 0.2 & 0.2 \\
\hline \multicolumn{13}{|c|}{ The time pattern to the multiplier for pattern 4 - Mosque } \\
\hline Periode & 1 & 2 & 3 & 4 & 5 & 6 & 7 & 8 & 9 & 10 & 11 & 12 \\
\hline Multiplier & 1 & 0 & 0 & 0.4 & 0.8 & 0.7 & 0.4 & 0.2 & 0.2 & 0.2 & 0.8 & 1 \\
\hline Periode & 13 & 14 & 15 & 16 & 17 & 18 & 19 & 20 & 21 & 22 & 23 & 24 \\
\hline Multiplier & 1 & 0.6 & 0.8 & 0.6 & 0.4 & 0.8 & 1 & 0.4 & 0.3 & 0.2 & 0 & 0 \\
\hline
\end{tabular}


simulation time period at the junction are made up of water quality. A valve is a link used to limit pressure or flow on the network. Its basic input consisted of initial and final node data, pipe diameter (millimeter), valve type and status (open or closed). The number of valves in this study was 13 with computational results such as flow and headloss.

\section{The Amount and Pattern of Drinking Water Demand}

In addition to the physical components used to make a series of networks, other components such as the curves of time pattern with multipliers were used to vary the time in accordance with the demand as presented in Table 1. The model of the time pattern curve type corresponds to the multiplier at each hour using the Lagrangian approach [17]. This pattern is used to determine the condition of the water movement in the pipe.

The time pattern used was divided into 4 types, namely, office, shop steady day, shift shop, and mosque. These patterns were used to obtain the maximum hours needed to analyze water hydraulics and FRC concentrations at each junction. The maximum/peak hours were at 6 am when work shift changes, and at $11 \mathrm{pm}$ during lunchtime. A total of 65 junctions with varying demands and values were used to channel water out of the Concentrating Division area as shown in Table 2.

\section{Hydraulics Simulation of Water Supply Distribution Networks}

The distribution network hydraulics was analyzed using an extended-period simulation (EPS) for 24 hours, where the calculation and reporting stages of hydraulics and water quality were carried out every hour with a pressure loss formula using Darcy-Weisbach (D-W). The pipe roughness coefficient using the D-W formula for HDPE pipes was $0.005 \mathrm{~mm}$ [17]. From the running results, changes occurred in each pipe such as the value of flow, velocity and headloss. Pressure conditions at each node were still sufficient to distribute water to all service junctions with pressures at peak hours ranging from 20.57 to 84.04 meters. Changes were observed only in conditions of maximum use because the flow affected the other water hydraulics. The higher the value of flow, the greater the velocity, which ranged from 0.04 to $4.68 \mathrm{~m} / \mathrm{s} \mathrm{X-X}$, as shown in Fig. 4 .

In addition, headloss was also influenced by the flow rate. Headloss values along with the distribution network during peak hours ranged from 0.06 to $79.39 \mathrm{~m} / \mathrm{km}$ as shown in Fig. 3. Hydraulic simulation results showed that the capacity of the distribution network using the gravity system was still capable of supplying water in terms of high pressure as shown in Fig. 3. High pressure was caused by high elevation differences at several points. In addition, it occurred due to low-pressure loss along the pipe as shown in Fig. 3. In addition, the low-pressure loss occurred because the HDPE pipe with a slippery/smooth surface which made a small friction factor was utilized. The simulation results showed the flow velocity at some point below $0.6 \mathrm{~m} / \mathrm{s}$ because it potentially caused the occurrence of laminar flow and water age sedimentation in the distribution network [20].

\section{Simulation of Free Residual Chlorine (FRC)}

Proper drinking water treatment and management routinely and sustainably conducted, is essential and protects public health [21]. Proper treatment produces high-quality water in accordance with established standards which aesthetically limits various physical, chemical and biological parameters. Drinking-water distribution systems (DWDS) have the ability to alter physical-chemical and biological parameters in water and cause a decay in its quality during distribution [22]. In general, color changes are due to the degradation effect in the DWDS which results in quality failures $[23,24]$.

In addition to natural microflora in river waters, it also contains allochthonous microorganisms which potentially endanger human health [24]. Apart from the results of human, agricultural and industrial activities, other factors such as rainfall and birds are also sources of microbiological contamination with coliforms as the most common [25]. The number of pathogenic bacteria in waters is dependent on the magnitude of flow, season, and geographical conditions of the river [24].

The amount of coliform in water depends not only on the environmental conditions but also on the season. Kadir and Nelson [26] stated that the inactivation of E. coli was highly dependent on the concentration of dissolved oxygen and the presence of UVB radiation which was associated with seasonal variations in the number of bacteria. Hema et al [27] also stated that most of the water spring samples in the rainy season contained higher coliform bacteria. This was because rainwater has the ability to move microbial pollutants that were accumulated in a watershed and flow into other river streams.

Various steps are carried out to remove microorganisms using the DWDS. Disinfection carried out using chlorine needs to sustain the presence of FRC to eliminate the re-growth of microorganisms in water distribution networks [28]. Chlorine undergoes decay due to reactions with organic and inorganic compounds in water and through liquid/solid reactions with biofilms, pipe walls and sediments. The required FRC concentration in water needs at least $0.2 \mathrm{mg} / \mathrm{L}$ to maintain bacteriological safety. The FRC concentration should not be more than $1 \mathrm{ppm}$, because higher concentrations cause taste and odor problems and increase the formation of by-products from disinfection [29]. In addition, other effects of excess FRC have the potential to produce a by-product compound 
Table 2. Water demands for each location.

\begin{tabular}{|c|c|c|c|c|c|}
\hline Location & Pattern & Demand (L/day) & Location & Pattern & Demand (L/day) \\
\hline Office Building 1-1 ${ }^{\text {st }} \mathrm{Fl}$. & 1 & $1,097.90$ & EI Building $3^{\text {rd }}$ Fl. & 3 & $2,330.24$ \\
\hline Office Building $1-2^{\text {nd }} \mathrm{Fl}$. & 1 & $1,097.90$ & EI Building Yard & 3 & $2,330.24$ \\
\hline Office Building $1-3^{\text {rd }} \mathrm{Fl}$. & 1 & $1,097.90$ & North South Mill 1 & 3 & $2,118.40$ \\
\hline Office Building $1-4^{\text {th }} \mathrm{Fl}$. & 1 & $1,097.90$ & North South Mill 2 & 3 & $2,118.40$ \\
\hline Office Building $1-5^{\text {th }} \mathrm{Fl}$. & 1 & $1,097.90$ & North South Mill 3 & 3 & $2,118.40$ \\
\hline Office Building 2-1 ${ }^{\text {st }} \mathrm{Fl}$. & 1 & $1,097.90$ & North South Mill 4 & 3 & $2,118.40$ \\
\hline Office Building 2-2 $2^{\text {nd }} \mathrm{Fl}$. & 1 & $1,097.90$ & North South Mill 5 & 3 & $2,118.40$ \\
\hline Office Building $2-3^{\text {rd }} \mathrm{Fl}$. & 1 & $1,097.90$ & North South Mill 6 & 3 & $2,118.40$ \\
\hline Office Building $2-4^{\text {th }} \mathrm{Fl}$. & 1 & $1,097.90$ & North South Mill 7 & 3 & $2,118.40$ \\
\hline Office Building $2-5^{\text {th }} \mathrm{Fl}$. & 1 & $1,097.90$ & North South Mill 8 & 3 & $2,118.40$ \\
\hline Amole Office & 2 & 970,93 & North South Mill 9 & 3 & $2,118.40$ \\
\hline HPGR Shop Yard & 3 & $2,330.24$ & North South Mill 10 & 3 & $2,118.40$ \\
\hline HPGR Office & 3 & $2,330.24$ & North South Mill 11 & 3 & $2,118.40$ \\
\hline SAG Office $1^{\text {st }} \mathrm{Fl}$. & 3 & $4,481.23$ & North South Mill 12 & 3 & $2,118.40$ \\
\hline SAG Office $2^{\text {nd }} \mathrm{Fl}$. & 3 & $4,481.23$ & North South Mill 13 & 3 & $2,118.40$ \\
\hline Security Office & 3 & $4,481.23$ & North South Mill 14 & 3 & $2,118.40$ \\
\hline SAG Yard & 3 & $4,481.23$ & Laboratory & 3 & $4,236.80$ \\
\hline Whitehouse Building & 3 & $4,481.23$ & Pump House Yard & 3 & $3,883.73$ \\
\hline Mill Control Room & 3 & $4,481.23$ & Pump House $1^{\text {st }} \mathrm{Fl}$. & 3 & $3,883.73$ \\
\hline SAG Pantry & 3 & $4,481.23$ & Pump House $2^{\text {nd }} \mathrm{Fl}$. & 3 & $3,883.73$ \\
\hline Leighton Shop 1 & 2 & $4,481.23$ & QC Laboratory $1^{\text {st }}$ Fl. & 3 & $4,236.80$ \\
\hline Leighton Shop 2 & 2 & $4,481.23$ & QC Laboratory $2^{\text {nd }} F 1$. & 3 & $4,236.80$ \\
\hline Leighton Shop 3 & 2 & $4,481.23$ & QC Laboratory $3^{\text {rd }} \mathrm{Fl}$. & 3 & $4,236.80$ \\
\hline Leighton SAG Mill & 2 & $2,240.62$ & Enggros Yard 1 & 2 & $3,883.73$ \\
\hline OJT Office & 2 & $4,481.23$ & Enggros Yard 2 & 2 & $3,883.73$ \\
\hline Routable Shop & 2 & $4,481.23$ & Enggros Yard 3 & 2 & $3,883.73$ \\
\hline New CMP $1^{\text {st }}$ Fl. & 3 & $2,330.24$ & Transfer Point Yard & 2 & 970.93 \\
\hline New CMP $2^{\text {nd }} \mathrm{Fl}$. & 3 & $2,330.24$ & Wet Screen & 3 & $2,330.24$ \\
\hline New CMP $3^{\text {rd }} F 1$. & 3 & $2,330.24$ & Old CMP $1^{\text {st }} \mathrm{Fl}$ & 3 & $2,330.24$ \\
\hline New CMP $4^{\text {th }} \mathrm{Fl}$. & 3 & $2,330.24$ & Old CMP $2^{\text {nd }} \mathrm{Fl}$. & 3 & $2,330.24$ \\
\hline New CMP $5^{\text {th }} \mathrm{Fl}$. & 3 & $2,330.24$ & Old CMP $3^{\text {rd }}$ Fl. & 3 & $2,330.24$ \\
\hline EI Building $1^{\text {st }} \mathrm{Fl}$. & 3 & $2,330.24$ & Mosque & 4 & 970.93 \\
\hline EI Building $2^{\text {nd }} \mathrm{Fl}$. & 3 & $2,330.24$ & & & \\
\hline
\end{tabular}

called Trihalomethane (THM) which is potentially carcinogenic.

In conducting FRC analysis due to loss of chlorine from bulk reactions and pipe walls, it is necessary to calculate the coefficient of reduction in free residual using data from field observations in the drinking water distribution system. The FRC degradation model of the pipe is dependent on the initial and final FRC values at a certain velocity along the flow distance as shown in Fig. 4.

The following formula (1), was used to obtain the decay rate constant in the distribution network of residual chlorine: 


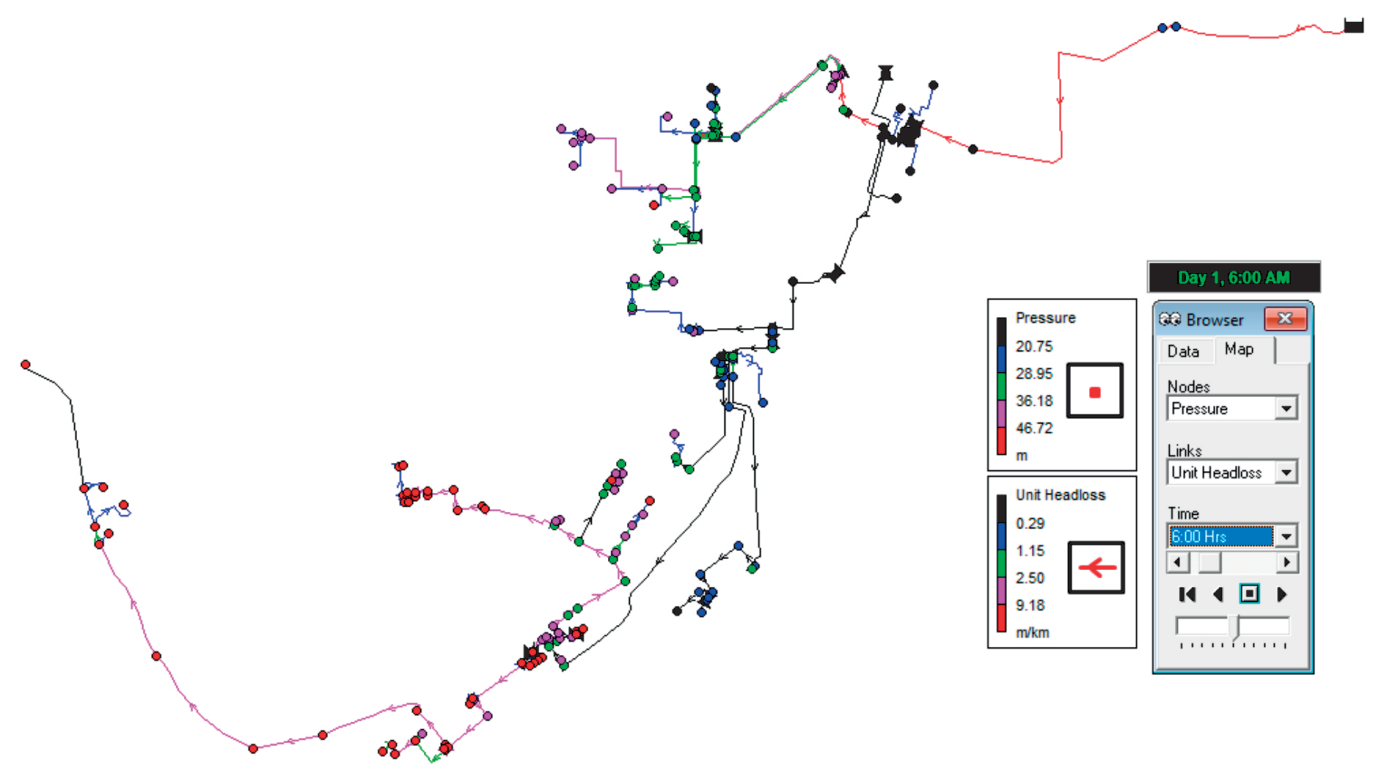

Fig. 3. Distribution of network pressure and headloss during peak hours.

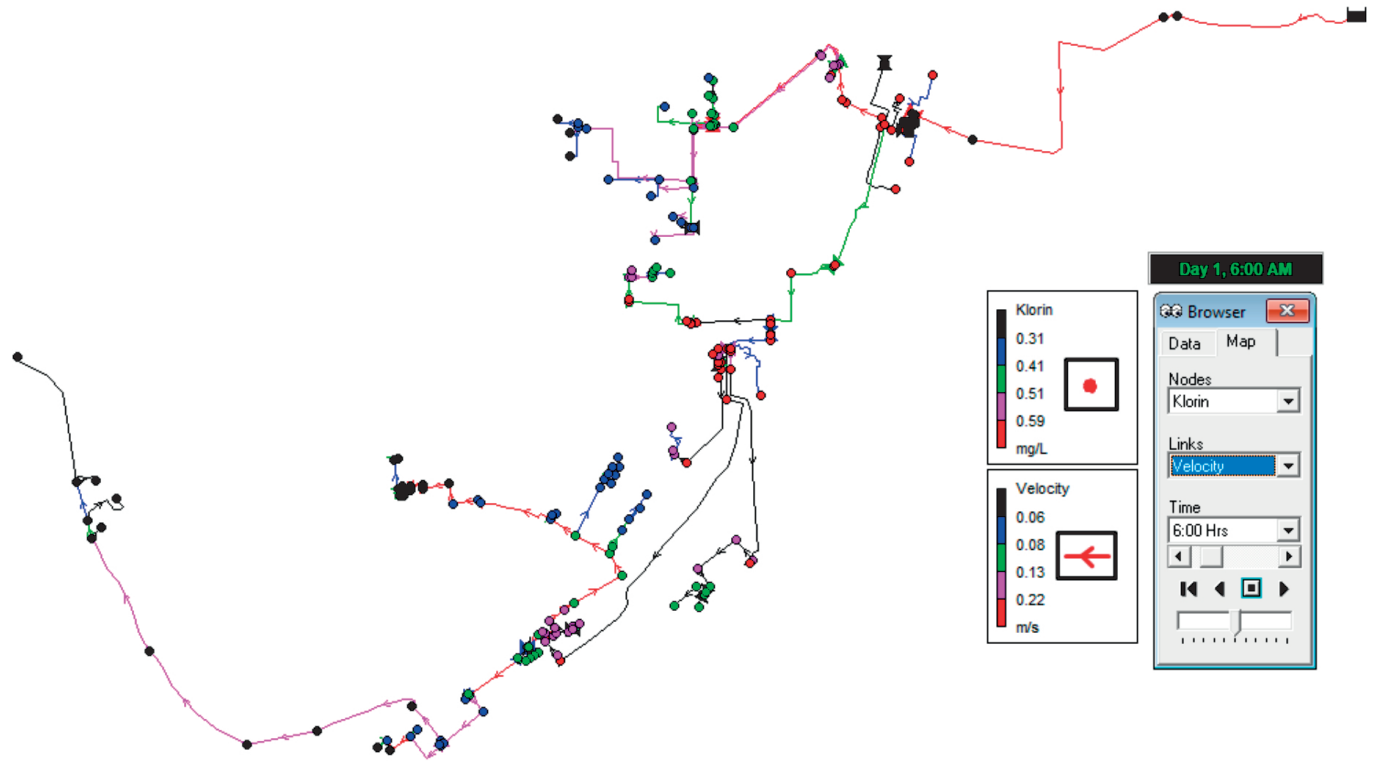

Fig. 4. Condition of distribution network FRC value and velocity during peak hours.

$$
\operatorname{Ln} \mathrm{C}_{\mathrm{e}}=\ln \mathrm{C}_{0}-\left(\frac{k}{v}\right) \mathrm{L}
$$

...where:

$\mathrm{C}_{\mathrm{e}}=$ Free residual chlorine concentration at a certain distance $(\mathrm{mg} / \mathrm{L})$

$\mathrm{C}_{\mathrm{o}}=$ Free residual chlorine concentration at $\mathrm{t}=0(\mathrm{mg} / \mathrm{L})$

$\mathrm{k}=$ Decay rate constant

$\mathrm{v}=$ Velocity $(\mathrm{m} / \mathrm{s})$

$\mathrm{L}=$ Flow distance $(\mathrm{m})$

The calculation results were obtained according to Table 3 .

The average coefficient value of the decayed free residual chlorine used by the EPAnet program is
-0.00033. After running the water on the EPAnet, the percentage of residual chlorine decayed as shown in Fig. 3. The bulk reaction value reduced to $4.48 \%$, due to the reactions in the flow such as low temperatures, water age in short pipes and spacing. This was supported by the research conducted by Liu, Reckhow and Li [30], which stated that the chlorine content in water decays faster at higher temperatures. Therefore, it was stated that the low-temperature conditions in the DWDS caused the reduced chlorine decay rate. According to Rossman (2000), the range of values for bulk and pipe wall reactions for the first-order reactions is $0-1,524 \mathrm{~m} /$ day. Further stated that the range values for bulk and wall reactions for pipes made of plastic 
Table 3. Calculation of the decay rate constant in free residual chlorine (FRC)

\begin{tabular}{|c|c|c|c|c|}
\hline $\begin{array}{c}\mathrm{C}_{0} \\
(\mathrm{mg} / \mathrm{L})\end{array}$ & $\begin{array}{c}\mathrm{Ce} \\
(\mathrm{mg} / \mathrm{L})\end{array}$ & $\begin{array}{c}\text { Length of pipe } \\
(\mathrm{m})\end{array}$ & $\begin{array}{c}\text { Velocity } \\
(\mathrm{m} / \mathrm{s})\end{array}$ & $\mathrm{K}$ \\
\hline 0.38 & 0.21 & $201.39 \mathrm{~m}$ & 0.17 & -0.00050 \\
\hline 0.40 & 0.20 & $201.39 \mathrm{~m}$ & 0.17 & -0.00058 \\
\hline 0.51 & 0.39 & $201.39 \mathrm{~m}$ & 0.17 & -0.00023 \\
\hline 0.52 & 0.44 & $201.39 \mathrm{~m}$ & 0.17 & -0.00014 \\
\hline 0.61 & 0.49 & $201.39 \mathrm{~m}$ & 0.17 & -0.00185 \\
\hline Average & & & & -0.00033 \\
\hline
\end{tabular}

the high-temperature conditions in Magelang city, Indonesia are $-1.68 /$ day and $-0.25 \mathrm{~m} /$ day, respectively $[17,31]$.

The reduction in free residual chlorine influenced by wall reaction was quite significant compared to the bulk reaction at $95.52 \%$. The percentage was influenced by the pipe and wall material such as the level of corrosion or biofilm and the age of the pipe [16, 17, 32]. Heim and Dietrich [33] stated that HDPE pipes need more chlorine than other plastic pipes. The first-order model was used to predict chlorine concentration in the distribution network. The model presents the amount of chlorine decay due to temperature, total organic carbon (TOC), and type of pipe material [34].

Colors are used to represent the residual chlorine in the EPAnet program. To determine the analysis of residual chlorine in the drinking water distribution network, a 24-hour simulation, was divided into two, namely peak hour and minimum conditions. The peak hour conditions were used to determine the ability of the residual chlorine concentration contained in the distribution network to meet quality standards. Additionally, the minimum conditions of usage were used to determine whether the residual chlorine concentration is below the permissible level, of $0.2 \mathrm{mg} / \mathrm{L}-1 \mathrm{mg} / \mathrm{L}$. The method used for chlorine application is 1 unit of booster located at the water treatment plant (WTP) before the water was distributed.

Fig. 5 shows percentage of reaction rate (kg/day) and Fig. 4 shows the residual chlorine at each drinking water distribution point during peak hours at $6 \mathrm{am}$. Fig. 4 shows that the lowest residual chlorine condition was $0.1 \mathrm{mg} / \mathrm{L}$.

The simulation results of distribution network hydraulics showed that the slow flow velocity at minimum conditions prolonged the water residence time in the pipeline. This led to an ineffective chlorine injection station in the tank.

The simulation showed that additional chlorine injection stations as boosters in some locations with FRC concentrations below $0.2 \mathrm{mg} / \mathrm{L}$. The use of the Query facility in the program, showed that a total of 6 nodes had FRC concentration below $0.2 \mathrm{mg} / \mathrm{L}$, with the lowest value at $0.1 \mathrm{mg} / \mathrm{L}$ as shown in Fig. 4 .

\section{Conclusions}

The drinking water distribution system in the Concentrating Division tends to supply water in accordance with the residual pressure on the network. This is influenced by variations of high elevation in

\section{Average Reaction Rates (kg/day)}

$\square 0.0$ Bulk $\square 0.0$ Wall $\square 0.0$ Tanks

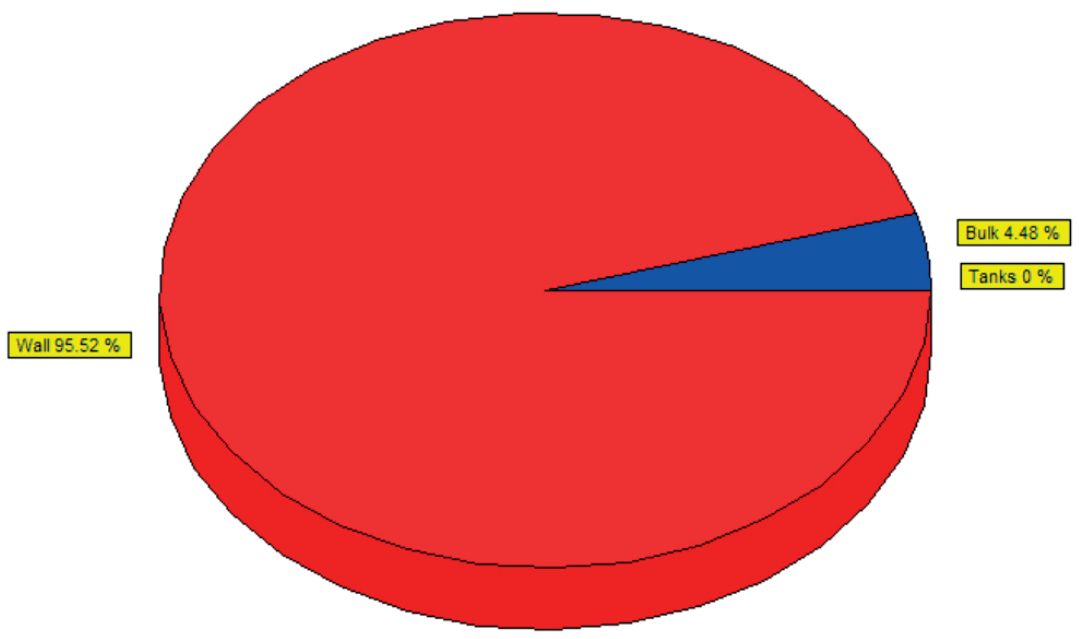

Fig. 5. Percentage of FRC decay. 
areas along the pipeline. Therefore, EPAnet was used to obtain accurate modeling of the FRC predictions which validated the results in the field. Every DWDS had different levels of chlorine decay rates. FRC concentrations are attected by the chlorine decay rate which in turn is influenced by the hydraulic behavior of the distribution network. The chlorine decay due to bulk reaction was $4.48 \%$ and wall reaction was $95.52 \%$. Approximately 1 unit of booster in the WTP was obtained at peak hours, the lowest FRC value was $0.1 \mathrm{mg} / \mathrm{L}$.

\section{Acknowledgements}

The authors are grateful to the Concentrating Division of PT Freeport Indonesia for their support, facilities provided and financial assistance.

\section{Conflict of Interest}

The authors declare no conflict of interest.

\section{References}

1. PERMANA D.S., THOMPSON L.G., SETYADI G. Tropical West Pacific moisture dynamics and climate controlson rainfall isotopic ratios in southern Papua, Indonesia. Journal of Geophysical Research: Atmospheres, 121, 2222, 2016.

2. SUSANTO A., PURWANTO P., HADIYARTO A. Analisis kualitas air untuk konsentrasi fluoride pada sistem jaringan distribusi air minum dengan. ENSAINS, 2 (1), 11, 2019.

3. SAKRAN T., MATOOQ P., EL-SHAHAWY G., SHALABY M., SABRY H., GAD M. Monitoring Water Quality Parameters in Egyptian Tap Water. Polish Journal of Environmental Studies, 28 (4), 2815, 2019.

4. DAUD M.K., NAFEES M., ALI S., RIZWAN M., BAJWA R.A., SHAKOOR M.B., ZHU S.J. Drinking Water Quality Status and Contamination in Pakistan. Biomed Research International, 2017, 1, 2017.

5. PARK K. Preventive and Social Medicine. (M/S Banarsidus Bhanot, Ed.) (25 $5^{\text {th }}$ ed.). Jabalpur, India: Prem Nagar. 2007.

6. LEEUWEN F.X.R. VAN. Safe Drinking Water: the Toxicologist's Approach. Food and Chemical Toxicology, 38, S51, 2000.

7. KHAN S.S., TAREEN H., JABEEN U., MENGAL F., MASOOD Z., AHMED S., MENGAL R. Quality Assessment of Drinking Water from the Different Colonies of Quetta City, Pakistan according to WHO Standards. Biological Forum: An International Journal, 7 (2), 699, 2015.

8. WIELEN P. VAN DER, LUT M.C. Distribution of microbial activity and specific microorganisms across sediment size fractions and pipe wall biofilm in a drinking water distribution system.: Water Supply, Water Science and Technology Water Supply, 16 (4), 896, 2016.

9. WINGENDER J., FLEMMING H. Biofilms in Drinking Water and their Role as Reservoir for Pathogens.
International journal of hygiene and environmental health, 214 (6), 417, 2011.

10. PONSADAILAKSHMIA S., SANKARIB S.G., PRASANNAC S.M., MADHURAMBAL G. Evaluation of water quality suitability for drinking using drinking water quality index in Nagapattinam district, Tamil $\mathrm{Nadu}$ in Southern India. Groundwater for Sustainable Development, 6, 43, 2018.

11. TABOR M., KIBRET M., ABERA B. Bacteriological and physicochemical quality of drinking water and hygiene sanitation practices of consumnes in Bahir Dar City, Ethiopia. Journal of Health Science., 21 (1), 19, 2011.

12. ESHCOL J., MAHAPATRA P., KESHAPAGU. Is fecal contamination of drinking water after collection assosiated with household water handling and hygiene practice? A study of urban slum households in Hyderabad, India. Water and Health, 7 (1), 145, 2009.

13. AMALI S., FADDOULI N.E.L., BOUTOULOUT A. Machine Learning and Graph Theory to Optimize Drinking Water. Procedia Computer Science, 127, 310, 2018.

14. GALAL-GORCHEV H. Chlorine in water disinfection. Pure and Applied Chemistry, 68 (9), 1731, 1996.

15. WORLD HEALTH ORGANIZATION. Guidelines for drinking water quality. Retrieved November 12, 2019, from https://apps.who.int/iris/bitstream/ handle/10665/44584/9789241548151_eng.pdf;jsessionid= 5961DCE3C1D7630846D3BDB29977C7A4? sequence $=1$ 2011.

16. MAYS L. Water Distribution Systems Handbook (McGhee.). New York: McGraw-Hill Book Co. 1999.

17. UNITED STATES ENVIRONEMNTAL PROTECTION AGENCY. EPANET 2 Users Manual. Retrieved August 18, 2019, from online: https://nepis.epa.gov/Adobe/PDF/ P1007WWU.pdf 2000.

18. MOHAMMAD K., MORTEZA A., MARK L. Potential for pathogen intrusion during pressure transients. American Water Works Association, 95 (5), 134, 2003.

19. MCGHEE T.J., STEEL E.W. Water supply and sewerage. (InMcGraw-Hill, Ed.) (6 $6^{\text {th }}$ ed.). New York, United States: McGraw-Hill. Retrieved from http://www.worldcat.org/ title/water-supply-and- sewerage/oclc/21440985 1991.

20. TRIFUNOVIC N. Introduction to Urban Water Distribution. (Taylor and Francis Ltd, Ed.). LOndon, United Kingdom: UNESCO-IHE Lecture Note Series. 2006.

21. FISH K., OSBORN A.M., BOXALL J.B. Biofilm structures (EPS and bacterial communities) in drinking water distribution systems are conditioned by hydraulics and in fluence discolouration. Science of the Total Environment, 593-594, 571, 2017.

22. VREEBURG J.H., BOXALL J. Discolouration in potable water distribution systems: a review. Water Research, 41 (3), 519, 2007.

23. GINIGE M.P., WYLIE J., PLUMB J. Influence of biofilms on iron and manganese deposition in drinking water distribution systems. Biofouling, 27 (2), 151, 2011.

24. AUGUSTYN L., BABULA A., JONIEC J., STANEKTARKOWSKA J., HAJDUK E., KANIUCZAK J. Microbiological Indicators of the Quality of River Water, Used for Drinking Water Supply. Polish Journal of Environmental Studies, 25 (2), 511, 2016.

25. SHELLENBARGER G.G., ATEARN N.D., TAKEKAWA J.Y., BOEHM A.B. Fecal indicator bacteria and Salmonella in ponds managedas bird habitat, San Francisco Bay. California, USA. Water Research, 42 (12), 2921, 2008. 
26. KADIR K., NELSON K.L. Sunlight mediated inactivation mechanisms of Enterococcus faecalis and Escherichia coli in clear water versus waste stabilization pond water. Water Research, 50 (1), 307, 2014.

27. HEMA C.N., PADMALAL D., JOSEPH A. Hydrochemical assessment of tropical springs - a case study from SW India. Environmental Monitoring and Assessment, 187 (2), 48, 2015

28. HASSANI A.H., JAFARI M.A., TORABIFAR B. Trihalomethanes Concentration in Different Components of WaterTreatment Plant and Water Distribution System in the North of Iran. International Journal of Environmental Research, 4 (4), 887, 2010.

29. KASTL G., FISHER I., JEGATHEESAN V., CHANDY J., CLARKSON K. Prediction of chlorine and trihalomethanes concentration profile in bulk drinking water distribution systems from laboratory data. Water Science and Technology, 3 (1-2), 239, 2003.

30. LIU B., RECKHOW D.A., LI Y.A. Two-site Chlorine Decay model For The Combined Efects Of $\mathrm{pH}$, Water
Distribution Temperature And In-home Heating Profiles using Differential Evolution. Water Research, 53, 47, 2014.

31. TRIATMADJA R., AL-AMIN M.B., KAMULYAN B. Numerical Simulation of Water Quality in A Pipe Network. In The First Makassar International Conference on Civil Engineering (MICCE2010), 9-10 Maret 2010. Makasar. 2010.

32. AL-JASSER A.O. Chlorine decay in drinking water transmission and distribution systems: pipe service age effect. Water Resources, 41 (2), 827, 2007.

33. HEIM T.H., DIETRICH A.M. Sensory Aspects And Water Quality Impacts of Chlorinated And Chloraminated Drinking Water In Contact With HDPE And PVC Pipe. Water Research, 41 (4), 757, 2006.

34. HALLAM N.B., WEST J.R., FORSTER C., POWELL J., SPENCER I. The decay of chlorine associated with the pipe wall in water distribution systems. Water Research, 36 (14), 3479, 2002. 